\title{
Western blot analysis of staphylococcal antibodies present in human sera during health and disease
}

\author{
J. A. BELL, T. H. PENNINGTON and DIANE T. PETRIE \\ Department of Bacteriology, University of Aberdeen, Foresterhill, Aberdeen AB9 $2 Z D$
}

\begin{abstract}
Summary. IgG antibodies directed against Staphylococcus aureus were examined by Western blotting in sera from 15 healthy individuals isolated for a year in Antarctica. Sera reacted with many staphylococcal antigens in whole-cell extracts and individuals showed unique and unchanging blot profiles. The IgG and IgM profiles of patients with deep-seated staphylococcal infections were also examined by Western blotting. Anti-staphylococcal IgM antibodies that reacted with an antigen of apparent molecular mass $31 \times 10^{3}$ were present in all patients with staphylococcal disease, and were absent from, or detected in much smaller amounts in, control sera.
\end{abstract}

\section{Introduction}

The almost universal presence of anti-staphylococcal antibodies in human serum has been well documented (Rogers and Melly, 1965; Ekstedt, 1974). Recent work on such antibodies has centred on the development of serological tests for deepseated staphylococcal disease. Several antibodies have been assessed for their diagnostic potential, including those directed against $\alpha$ haemolysin (Towers and Gladstone, 1958; Larinkari and Valtonen, 1984), teichoic acid (Crowder and White, 1972; Shaegren, 1984), $\gamma$ haemolysin (Taylor and Plommet, 1973) and staphylococcal nuclease (Taylor et al., 1976). Their value in the diagnosis of deep-seated infection is limited (Parker, 1984).

In this study, the Western blot technique (Burnette, 1981) has been used to examine the immune response of individuals to the large number of polypeptides found in whole-cell extracts of Staphylococcus aureus. The result of a longitudinal study of workers in Antarctica over periods of up to a year were compared with results from studies on blood-donor sera, and sera from patients with deepseated staphylococcal infections.

The objective of this study was to establish the limits of individual and chronological variation in the serological response to $S$. aureus by healthy adults and to assess differences in blot profiles between healthy individuals and patients with deep-seated staphylococcal infections.

Received 10 Jan. 1986; accepted 2 Apr. 1986.

\section{Materials and methods}

\section{Serum samples}

(i) Sera were collected monthly from 15 men living on an Antarctic base from Apr. 1983 to Mar. 1984; nine men were present for the whole study period. Their average age was 27 years (range $22-37$ years); all were fit and healthy, had no record of serious staphylococcal infection, and did not suffer from any staphylococcal infections during the study period. (ii) Sera were taken from 30 blood donors, of whom 16 were men. The average age of this group was 34 (range 22-49) years. (iii) Eight sera from six patients with staphylococcal osteomyelitis were obtained from Dr R. R. Marples, Division of Hospital Infection, Central Public Health Laboratory, Colindale. Sera were separated, centrifuged at $1600 \mathrm{~g}$ and stored at $-20^{\circ} \mathrm{C}$.

\section{Serological estimations}

Antibody titres against $\alpha$-haemolysin were estimated with Rapi Tex-AStal kits, supplied by the Behring Institute, Marburg, W. Germany; this is an agglutination test with polystyrene beads coated with haemolysin. Antibody titres against nuclease were estimated by the method devised by Taylor et al. (1976) in which the substrate is DNA and the indicator is methyl green. Antibody titres against teichoic acid were estimated by Endo-Staph Ouchterlony plates supplied by Meridian Diagnostics Inc., Cincinnati, $\mathrm{OH}, \mathrm{USA}$.

\section{Preparation of staphylococcal polypeptides}

A strain of $S$. aureus isolated in this department in 1984 (phage type: RTD $29+, 100$ RTD 29/52/80+) was used throughout the study. The bacteria were grown 
overnight in nutrient broth with agitation in an orbital incubator at $37^{\circ} \mathrm{C}$. Organisms were harvested by centrifugation at $2500 \mathrm{~g}$ for $20 \mathrm{~min}$ at $4^{\circ} \mathrm{C}$ and the supernate removed. The staphylococcal pellet was transferred into a Microfuge (Beckman 8) tube which was centrifuged in the Microfuge for $5 \mathrm{~min}$. The supernate was removed and the pellet resuspended in an equal volume of distilled water. The organisms were disrupted by sonication with a Rapidis 150 Sonicator (Ultrasonic Ltd, Shipley, Yorks) emitting $45 \mathrm{~W}$ at full power output. A large probe was used for $5 \mathrm{~min}$, samples being cooled in melting ice throughout. Protein concentrations were measured by Bradford's method (1976); the final sonicated sample contained about $0.45 \mathrm{~g} / \mathrm{L}$.

Staphylococcal proteins were prepared by mixing $0.2 \mathrm{ml}$ of bacterial extract with $0.1 \mathrm{ml}$ of reducing buffer containing sodium dodecyl sulphate $4 \% \mathrm{w} / \mathrm{v}, 2$-mercaptoethanol $5 \% \mathrm{v} / \mathrm{v}$, glycerol $10 \% \mathrm{v} / \mathrm{v}, 0.0625 \mathrm{M}$ Tris base and bromophenol blue. The mixture was then boiled for $5 \mathrm{~min}$.

Polypeptides were separated by sodium dodecyl sulphate polyacrylamide gel electrophoresis (SDS-PAGE) in $10 \%$ polyacrylamide, with a $3.6 \%$ stacking gel, and with the discontinuous buffer system of Laemmli (1970). The gels were electrophoresed in a Mk 1 Protean double slab vertical electrophoresis cell (Bio-Rad).

The polypeptides were transferred on to nitrocellulose filters (pore diameter $0.45 \mu \mathrm{m}$; Sartorius Schleicher and Schuell) by electrophoretic transfer by the method of Towbin et al. (1979) as modified by Burnette (1981). Transfer was done in a Bio-Rad transblotting cell at $70 \mathrm{~mA}$ for $14 \mathrm{~h}$ in blotting buffer ( $20 \mathrm{~mm}$ Tris, $150 \mathrm{mM}$ glycine and $20 \%$ glycine). After transfer the nitrocellulose paper was cut vertically into strips. These were washed twice in distilled water and soaked in a blocking buffer of sterile newborn bovine serum (Flow Laboratories) $10 \%$ in phosphate buffered saline (PBS) at $p \mathrm{H} 7.4$ and Triton-X $1000.2 \%$ for 30 min on a rocking platform (as with all subsequent steps). Strips were then treated with serum (diluted 1 in 20 or 50 ) for $90 \mathrm{~min}$. The strips were washed three times for $15 \mathrm{~min}$ with horseradish peroxidase-conjugated anti-human IgG or IgM (Miles-Yeda) at a dilution of 1 in 500 in blocking buffer, after which they were again washed thrice for $15 \mathrm{~min}$ each in blocking buffer, followed by a wash in PBS. Finally the strips were developed by soaking for $5 \mathrm{~min}$ in a staining solution containing $50 \mu \mathrm{g}$ of diamino-benzidine tetrahydrochloride and $1 \mathrm{ml}$ of $1 \% \mathrm{H}_{2} \mathrm{O}_{2}$ in $100 \mathrm{ml}$ of $0.1 \mathrm{M}$ Tris- $\mathrm{HCl}, p \mathrm{H}$ 7.6. The blots were allowed to dry and were then photographed.

Mol.-wt markers (Pharmacia) were run in some gels. Transferred polypeptides were stained by treating the nitrocellulose paper with Ponceau S stain for $2 \mathrm{~h}$ at room temperature, then washing for $2 \mathrm{~h}$ in distilled water.

\section{Results}

Comparison of identical nitrocellulose transfers stained by Ponceau $\mathrm{S}$ and by Western blot shows clear differences. Fig. 1 shows polypeptide transfers



Fig. 1. Nitrocellulose transfers of SDS-PAGE separations of $S$. aureus whole-cell extracts (tracks 2 and 3) and mol.-wt markers (track 1). Tracks 1 and 2 stained with Ponceau S; track 3, Western blot of human serum from subject in the antarctic study stained for IgG.

taken from the same slab gel. Tracks 1 and 2 were stained with Ponceau S, and track 3 was allowed to react with serurn from a subject from the Antarctic group to show the IgG response. A larger number of bands (44) was resolved in the Western blot of the $S$. aureus extract than in the Ponceau S-stained transfer ( 34 bands). The most prominent bands in the stained transfer had mol. wts $\left(10^{3}\right)$ of $74,58,55$, $51,35,32,23$ and 17 . They were not prominent in the Western blot of the same extract that showed strongly staining bands with apparent mol. wts $\left(10^{3}\right)$ of $67,34,31,30,28$ and 18 . Some major bands were seen in both stained and Western blot tracks. Other bands were detected only by either Western blot or stain.

The Western blot in fig. 2 shows a typical sequential monthly IgG profile of the sera of a subject in the Antarctic group taken during the course of a year. The band profile shows no change during the study period; similar results were 




Fig. 2. Western blot of sera taken at monthly intervals from a single individual with $S$. aureus whole-cell extract; stained for IgG. Numbers indicate month of sampling.

obtained in the other 14 subjects (not shown). When the IgG Western blot profiles of individuals were compared by allowing a serum sample from each to react with identical strips of a single $S$. aureus extract, marked similarities with dominant bands appearing in tests with sera from each subject at positions representing mol. wts $\left(10^{3}\right) 84,74,64,34$, $31,30,28$ and 18 were apparent (fig. 3). Differences in band pattern and band intensity from individual to individual were also seen; however, several bands with apparent mol. wts $\left(10^{3}\right)$ of $34-28$ varied in position and intensity from subject to subject. Other variant bands included: the $69 \times 10^{3}$-mol. wt band in track $\mathrm{L}$ that stained more intensely than in

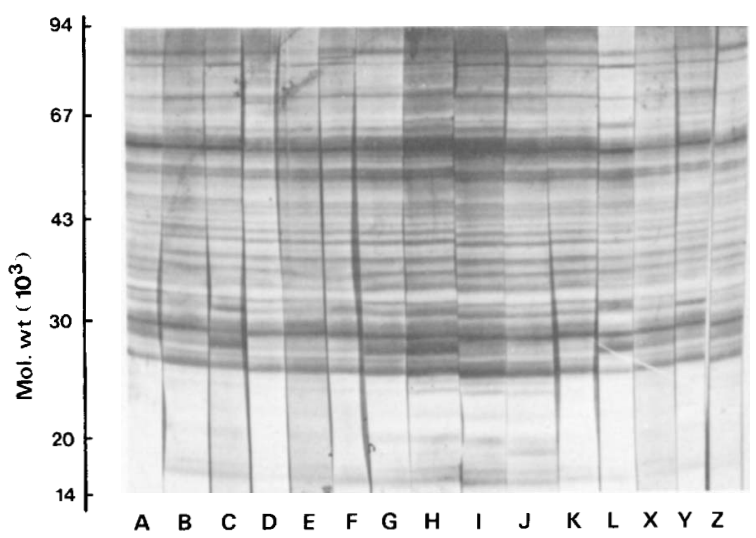

Fig. 3. Western blot of sera from 15 healthy individuals (Antarctic group) with $S$. aureus whole-cell extract; stained for IgG. other tracks; the $34 \times 10^{3}$-mol. wt band that showed denser staining in tracks $\mathrm{C}, \mathrm{F}, \mathrm{H}, \mathrm{I}, \mathrm{L}$ and $\mathrm{Y}$; the $32 \times 10^{3}$ - and $29 \times 10^{3}$-mol. wt bands that were almost absent in track $\mathrm{L}$; the $30 \times 10^{3}$-mol. wt band that was more intense in tracks $A, C, G, H$ and $L$; and the $18 \times 10^{3}$-mol. wt band that was very weak in test with sera from subjects $\mathrm{A}, \mathrm{K}$ and $\mathrm{L}$.

Sera from six patients with staphylococcal osteomyelitis and with elevated antistaphylococcal nuclease, staphylolysin or teichoic acid antibody titres (see table) were compared by Western blot with controls. Tracks $1 \mathrm{a}-6$ in fig. 4 show the IgG Western blot of the sera of patients with staphylococcal infections. Tracks $7-10$ are blots of sera from healthy controls (Antarctic group). The pattern of each strip is similar to those in the previous figures, with many common prominent bands but with individual variations from strip to strip. Fig. 5 shows the IgM Western blot profile of the same group of test sera. Antibodies in all sera reacted with polypeptides with mol. wts $\left(10^{3}\right) 84,64,58$ and 18. Sera from patients with deep-seated staphylococcal infections contained antibody that reacted with a polypeptide of mol.wt $31 \times 10^{3}$, stain intensity being especially prominent in tracks $1 \mathrm{a}-$ $2 b$ and less in tracks 3-6. Antibody against this polypeptide was detected only in one of the control sera, and then in a trace amount. The band at mol. wt $74 \times 10^{3}$ appeared to be strongest in tracks $1,2,3,5,6$ and 7 . There was a band at mol. wt $23 \times$ $10^{3}$ that appeared only in tracks $1 \mathrm{a}$ and $\mathrm{b}$ which had been treated with sera from the same patient taken 3 weeks apart. There was a unique band at mol. wt $72 \times 10^{3}$ in track 5 . The control sera did not appear to have any unique bands.

Sera $1 \mathrm{a}$ and $1 \mathrm{~b}$, and $2 \mathrm{a}$ and $2 \mathrm{~b}$ were pairs taken from the same individuals 3 weeks apart. Particularly noteworthy was the marked decline in intensity

Table. Antibody titres against three staphylococcal antigens in the sera of patients with osteomyelitis

\begin{tabular}{cccc}
\hline Serum no. & $\begin{array}{c}\text { Anti- } \\
\text { nuclease } \\
\text { titre }\end{array}$ & $\begin{array}{c}\text { Anti-staphylo- } \\
\text { lysin }(\alpha \text { haemoly- } \\
\text { sin) titre }\end{array}$ & $\begin{array}{c}\text { Anti-teichoic } \\
\text { acid titre }\end{array}$ \\
\hline $1 \mathrm{a}^{*}$ & 128 & 8 & 2 \\
$1 \mathrm{~b}^{*}$ & 128 & 8 & 4 \\
$2 \mathrm{a}^{*}$ & 128 & 8 & 2 \\
$2 \mathrm{~b}^{*}$ & 16 & 8 & 1 \\
3 & 64 & 2 & 1 \\
4 & 32 & 8 & 1 \\
5 & 32 & 8 & 1 \\
6 & 32 & 8 &
\end{tabular}

* a, b-sequential sera taken 3 weeks apart from the same patient. 


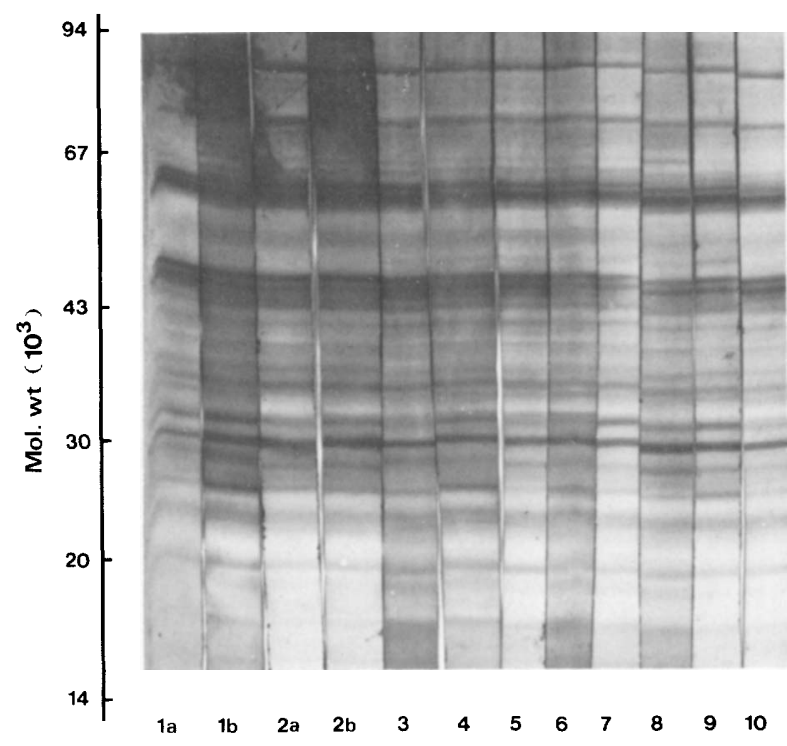

Fig. 4. Western blot of sera from patients with deep seated staphylococcal infections (tracks 1-6) and healthy Antarcticgroup controls (tracks 7-10); stained for IgG. Numbers 1-6 indicate indentity of patients; $1 \mathrm{a}, 1 \mathrm{~b}$, and $2 \mathrm{a}, 2 \mathrm{~b}$ are sequential sera from patients 1 and 2 respectively, $b$ taken 3 weeks after $a$.

of staining of polypeptides of mol. wt $31 \times 10^{3}$ when sera $2 \mathrm{a}$ and $2 \mathrm{~b}$ were compared; a similar decline in titre was apparent in the anti-staphylococcal nuclease titres of these sera.

\section{Discussion}

This study has clearly demonstrated that all the individuals investigated produce circulating $\mathrm{IgG}$ antibodies directed against a large number of

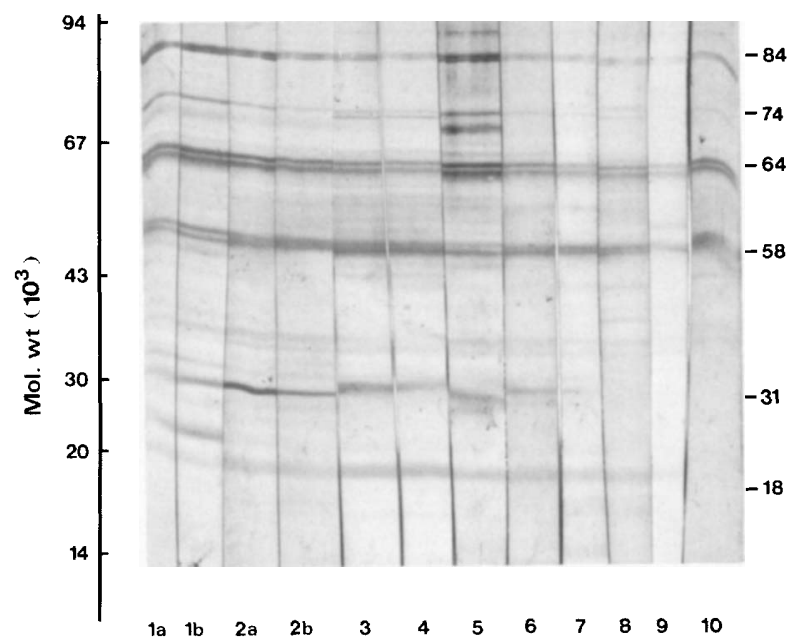

Fig. 5. Western blot of sera from patients and healthy Antarcticgroup controls arranged as in fig. 4 ; stained for IgM.
$S$. aureus polypeptides. This finding is in broad agreement with those of other workers who have found that most human sera possess a variety of anti-staphylococcal antibodies (Oeding et al., 1981). Despite the complexity of the immune response, many polypeptides in the cell extract gave negative reactions in the Western blot analysis. It is likely that the immune response against some polypeptides may be poor because they are intrinsically poor antigens, because of their structure or other factors. It is also probable that antigenic sites on some polypeptides are irreversibly lost after denaturation by SDS and mercaptoethanol treatment. That all adults mount a comprehensive and similar immune response to $S$. aureus (both quantitatively and qualitatively) is surprising in view of the fact that only about $40 \%$ of individuals are carriers of the organism (Williams, 1966).

The individual differences in blot profiles of sera from different subjects may, in part, be due to differences in the staphylococcal strains carried by these individuals. We have shown recently that whereas SDS-PAGE of cell extracts of different strains of $S$. aureus show little difference after Coomassie blue staining, the supernates of broth cultures show markedly different Western blot profiles (Krikler et al., 1986). It is reasonable to suppose that such differences in the production of exported proteins may be accompanied by differences in the immune response to such strains. Furthermore, profiles may differ because individuals respond to some antigens in different ways. Such variations in immune response have been observed in the toxic shock syndrome (Todd et al., 1978), in which only $20 \%$ of sufferers possess the antibody against TSST-1 (enterotoxin F), whereas this antibody is found in $80 \%$ of controls (Bergdoll et al., 1981), suggesting that sufferers from the syndrome may respond less well to the toxin in terms of circulating antibody production than other individuals.

Western blots of the IgG responses of patients with staphylococcal disease and controls did not show features unique to the infected group; there was no evidence of an immune response strongly associated with staphylococcal infection. The antistaphylococcal IgM studies showed very different blot profiles; many fewer bands were stained. Antibody reacting with an antigen of mol. wt $31 \times$ $10^{3}$ was found in all the sera from patients examined, and, with one exception, was absent from the control sera. In recent Western blot studies with other micro-organisms similar results have been found. For example, in studies of the serological response to invasive aspergillosis, Mathews et 
al. (1985) found that antibodies to the $40 \times 10^{3}$ mol. wt component of the fungal pressate were present in 13 of 16 patients, but not in any of 10 controls. This response was, however, found in both classes of antibody investigated-IgG and IgM.

Our studies have shown that Western blot analyses of the IgG class of antibodies in deepseated staphylococcal disease are unlikely to be of immediate diagnostic value; the complexity of the immune response of healthy individuals, together with variations between such individuals, makes analysis of single serum samples difficult. Changes

\section{REFERENCES}

Bergdoll M S, Crass B A, Reiser R F, Robbins R N, Davis J P 1981 A new staphylococcal enterotoxin, enterotoxin $F$, associated with toxic-shock-syndrome Staphylococcus aureus isolates. Lancet 1: 1017-1021.

Bradford M M 1976 A rapid and sensitive method for the quantitation of microgram quantities of protein utilizing the principle of protein-dye binding. Analytical Biochemistry 72: $248-254$.

Burnette W N 1981 "Western Blotting": Electrophoretic transfer of proteins from sodium dodecyl sulfate-polyacrylamide gels to unmodified nitrocellulose and radiographic detection with antibody and radioiodinated protein A. Analytical Biochemistry 112: 195-203.

Crowder J G, White A 1972 Teichoic acid antibodies in staphylococcal and nonstaphylococcal endocarditis. Annals of Internal Medicine 77: 87-90.

Ekstedt R D 1974 Immune response to surface antigens of Staphylococcus aureus and their role in resistance to staphylococcal disease. Annals of the New York Academy of Sciences 236 : 203-219.

Krikler S J, Pennington T H, Petrie D 1986 Typing of strains of Staphylococcus aureus by Western blot analysis of culture supernates. Journal of Medical Microbiology 21 : 169-171.

Laemmli U K 1970 Cleavage of structural proteins during the assembly of the head of bacteriophage T4. Nature 227: 680685.

Larinkari U, Valtonen V V 1983 Comparison of anti alpha haemolysin and teichoic acid antibody tests in patients with endocarditis and septicaemia caused by Staphylococcus aureus. Scandinavian Journal of Infectious Diseases Supplement 41 : 144-145.

Matthews R, Burnie J P, Fox A, Tabaqchali S 1985. Immunoblot in antibody profile detected by Western blot analysis of serial samples might prove more helpful. The $\mathrm{IgM}$ response to the $31 \times 10^{3}$-mol. wt antigen shown by sera from patients with deep-seated infection may, however, prove to be of diagnostic value, and further studies are in progress to evaluate this possibility.

We thank the British Antarctic Survey for financial support and Dr R. R. Marples, Division of Hospital Infection, Central Public Health Laboratory, Colindale, for his help in providing sera samples, reagents and advice and for the estimations of anti-staphylolysin and anti-nuclease antibody titres.

analysis of serological responses in invasive aspergillosis. Journal of Clinical Pathology 38: 1300-1303.

Oeding P, Natas O B, Fleurette J 1981 Detection of staphylococcal antibodies in human sera. In: Macdonald $A$ and Smith $\mathrm{G}$ (eds). The staphylococci. Aberdeen University Press, Aberdeen. p 97.

Parker M T 1984 Staphylococcal diseases. In: Wilson G S et al. (eds). Topley and Wilson's principles of bacteriology, virology and immunity, vol 3, 7th edn. Edward Arnold, London, p 269.

Rogers D E, Melly M A 1965 Speculations on the immunology of staphylococcal infections. Annals of the New York Academy of Sciences 128: 274-284.

Shaegren J 1984 Staphylococcus aureus. The persistent pathogen (Second of two parts). New England Journal of Medicine 310: $1437-1442$.

Taylor A G, Plommet M 1973 Anti-gamma haemolysin as a diagnostic test in staphylococcal osteomyelitis. Journal of Clinical Pathology 26: 409-412.

Taylor A G, Fincham W J, Cook J 1976 Staphylococcal antibodies in osteomyelitis: the use of anti-staphylococcal nuclease levels in diagnosis. In: Jeljaszewicz $\mathbf{J}$ (ed) Staphylococci and staphylococcal diseases. Gustav Fischer, Stuttgart, pp 911-916.

Todd J, Fishaut M, Kapral F, Welch T 1978 Toxic-shock syndrome associated with phage-group-1 staphylococci. Lancet 2: 1116-1118.

Towbin H, Staehelin T, Gordon J 1979 Electrophoretic transfer of proteins from polyacrylamide gels to nitrocellulose sheets : procedure and some applications. Proceedings of the National Academy of Science of the USA 76: 4350-4354.

Towers A G, Gladstone G P 1958 Two serological tests for staphylococcal infection. Lancet 2 : 1192-1195.

Williams R E O 1966 Epidemiology of airborne staphylococcal infection. Bacteriological Reviews 30: 660-674. 